\begin{tabular}{|c|c|c|}
\hline $\mathrm{Ar}$ & $\begin{array}{c}\text { European Association for the } \\
\text { Development of Renewable Energies, Environment } \\
\text { and Power Quality (EA4EPQ) }\end{array}$ & $\begin{array}{l}\text { International Conference on Renewable Energies and Power Quality } \\
\text { (ICREPQ'12) } \\
\text { Santiago de Compostela (Spain), 28th to 30th March, } 2012\end{array}$ \\
\hline
\end{tabular}

\title{
Modelling, Iterative Procedure and Simulation Results for a Monocrystalline Solar Cell
}

\author{
S. Saraiva ${ }^{1}$, R. Melício ${ }^{1,2}$, J.C.O. Matias ${ }^{1}$, C.M.P. Cabrita ${ }^{1}$ and J.P.S. Catalão ${ }^{1,2}$ \\ ${ }^{1}$ University of Beira Interior and CAST \\ R. Fonte do Lameiro, 6200-001 Covilhã (Portugal) \\ Phone: +351275 329 914, Fax: +351275329972 \\ e-mail: ssaraiva@gmail.com, ruimelicio@gmail.com, matias@ubi.pt, cabrita@ubi.pt \\ ${ }^{2}$ Center for Innovation in Electrical and Energy Engineering, Instituto Superior Técnico \\ Av. Rovisco Pais 1, 1049-001 Lisbon (Portugal) \\ Phone: +351218417 000, Fax: +351218499242 \\ e-mail: catalao@ubi.pt
}

\begin{abstract}
This paper focuses on the modelling and simulation for a photovoltaic system formed by monocrystalline solar modules. The objective is to find the parameters of the nonlinear I-V equation by adjusting the curve at three points: open circuit, maximum power, and short circuit. This paper brings a novel iterative procedure to find the value of diode ideality factor, series and equivalent shunt resistances. Simulation studies are carried out in order to uncover temperature dependence, solar radiation change, and output power variation. Finally, conclusions are duly drawn.
\end{abstract}

\section{Key words}

Photovoltaic energy, solar cells, modelling, simulation, iterative procedure.

\section{Introduction}

Renewable energy resources will play a significant role in the world energy supply in the upcoming future. Among the renewable energy resources, solar energy has ubiquity and abundance [1]. Solar energy is the primary source for other types of renewable energy, except tide and geothermal energy. It is accessed in almost all parts of the earth and has an excellent sustainability.

In recent years, significant photovoltaic (PV) deployment has occurred, particularly in Germany, Spain and Japan [2]. Apart from the solar thermal plants, the spreading of PV systems is being encouraged by the feed-in tariffs and by the drop in crystalline cells' prices [3].

Also, PV energy is expected to become an important player in the coming years in Portugal, since it is one of the European countries with the highest levels of solar radiation. Sunshine in mainland Portugal varies between 1800 and 3100 hours per year, so the country has a huge potential for solar energy exploitation.
The aim in Portugal is to reach $1500 \mathrm{MW}$ of installed capacity by 2020 , according to the Portuguese National Strategy ENE 2020, multiplying tenfold the existing capacity [4].

A PV array may be either a panel or a set of panels connected in series or parallel to form large PV systems. Power-electronic converters may be used to regulate the voltage and current at the load, to control the power flow in grid-connected systems, and for the maximum power point tracking (MPPT) of PV systems [5].

By far, the simplest equivalent electrical circuits approach is a current source in parallel with a diode [6]. An improved version is the inclusion of a series resistance in the equivalent electrical circuit approach and an extension of this version includes an additional shunt resistance, augmenting the number of parameters for four to five. This version is justified for modelling with improved accuracy and is followed in this paper.

\section{Modelling}

\section{A. Single-Diode, Series and Shunt Resistances}

The equivalent circuit model for a solar cell simulation with single-diode, series and equivalent shunt resistances, is shown in Figure 1.

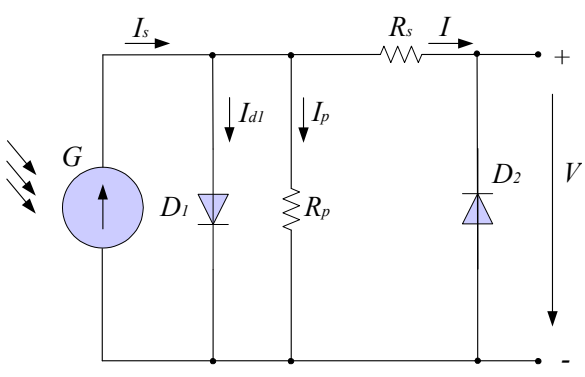

Fig. 1. Equivalent circuit of the solar cell. 
The equivalent circuit model can be used to simulate an individual cell, a module, an array or a panel. In Figure 1, $G$ is the solar irradiance, $I_{S}$ is the photo generated electric current, $I_{d l}$ is the current at diode $D_{l}, I_{p}$ is the leakage current, $R_{p}$ is the equivalent shunt resistance, $R_{s}$ is the series resistance, $I$ is the output current, $D_{2}$ is the by-pass diode and $V$ is the output voltage. The thermal voltage of the model is given by:

$V_{T_{1}}=\frac{k T_{1}}{q}$

where $V_{T l}$ is the thermal voltage at the cell temperature $T_{1}$ in Kelvin, $k$ is the Boltzman's constant, $q$ is the electron charge. The I-V characteristic associated with the model shown in Figure 1 for the solar cell is given by:

$I=I_{s}-I_{01}\left[e^{\frac{\left(V+R_{s} I\right)}{m_{1} V_{T_{1}}}}-1\right]-\frac{V+R_{s} I}{R_{p}}$

where $I_{01}$ is the diode reverse bias saturation current, $m_{l}$ is the diode ideality factor.

For constant irradiance and $p-n$ junction temperature conditions, the short circuit current is the greatest value of the current at the cell terminals. The short circuit current is given by:

$I_{s c}=I=I_{s}-I_{01}\left(e^{\frac{R_{s} I_{s c}}{m_{1} V_{T_{1}}}}-1\right)-\frac{R_{s} I_{s c}}{R_{p}}$

For constant irradiance and $p-n$ junction temperature conditions, the open circuit voltage is the greatest value of the voltage at the cell terminals. The open circuit voltage $V_{o c}$ is given by:

$V_{o c}=m_{1} V_{T_{1}} \ln \left(\frac{I_{s}}{I_{01}}+\frac{V_{o c}}{R_{p} I_{01}}+1\right)$

were:

$R_{\text {sho }}=-\left.\frac{d V}{d I}\right|_{I=I_{s c}}$

$R_{s o}=-\left.\frac{d V}{d I}\right|_{V=V_{o c}}$

The diode ideality factor is given by:

$$
m_{1}=\frac{V_{m}^{*}+R_{s o} I_{m}^{*}-V_{o c}^{*}}{V_{T_{1}}\left[\ln \left(I_{s c}^{*}-\frac{V_{m}^{*}}{R_{s h o}}-I_{m}^{*}\right)-\ln \left(I_{s c}^{*}-\frac{V_{o c}^{*}}{R_{p}}\right)+\frac{I_{m}^{*}}{I_{s c}^{*}-\left(\frac{V_{o c}^{*}}{R_{s h o}}\right)}\right]}
$$

where $V_{m}^{*}$ is the voltage for maximum power at STC, $I_{m}^{*}$ is the current for maximum power at STC, $V_{o c}^{*}$ is the open circuit voltage at STC, $I_{s c}^{*}$ is the short circuit current at STC, $I_{m}^{*}$ is the current for maximum power at STC.
The output power is given by:

$$
P=V\left[I_{s c}-I_{01}\left(e^{\frac{\left(V+R_{s} I\right)}{m_{1} V_{T_{1}}}}-1\right)-\frac{V+R_{S} I}{R_{p}}\right]
$$

\section{Iterative Procedure}

Each I-V characteristic curve specifies a unique operating point at which maximum possible power is delivered. This is the MPP, where the PV operates at its highest efficiency.

The data considered are the STC cell voltage for maximum power, current for maximum power, open circuit voltage, and short circuit current.

The goal for the novel iterative procedure proposed in this paper is to find the value of diode ideality factor, series and equivalent shunt resistances, with a very good approximation in the neighbourhood around the maximum of the I-V curve, since this is the aimed operation point. The Newton-Raphson method is used in the proposed iterative procedure due to the ability to overcome undesired behaviours.

The iterative procedure to adjust the I-V output characteristics of the solar cell is shown in Figure 2.

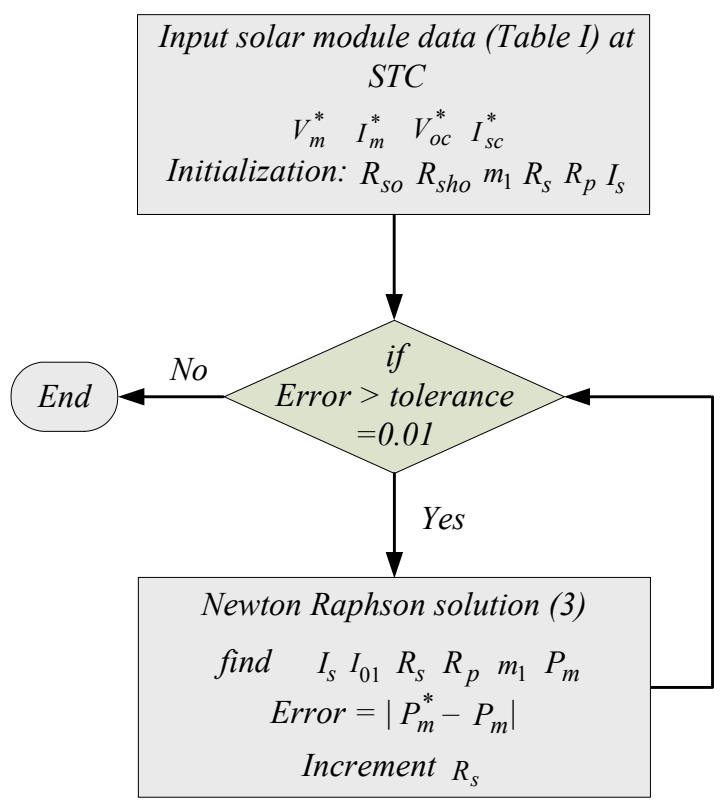

Fig. 2. Iterative procedure to adjust the I-V output characteristics of the solar cell.

Plotting the I-V characteristic curves requires solving (2) for $I \in\left[0, I_{s c}\right]$ and $V \in\left[0, V_{o c}\right]$. Equation (2) does not have an explicitly, i.e., that is $I=f(V, I)$ or $V=f(I, V)$ are implicit equations. Hence, numerical methods have to be used and this imposes an adequate formalism, for instance, writing the $\mathrm{I}-\mathrm{V}$ as $g(V, I)=I-f(V, I)=0$ points are easy obtained by numerically solving for a set of terminal voltage values, obtaining the corresponding set of output current points. 


\section{Simulation Results}

The mathematical models for the solar cell with singlediode, series and shunt resistances were implemented in Matlab/Simulink. Table 1 summarizes the data for the monocrystalline solar cell at STC referenced in [7].

Table I. - Solar cell data for BP4175 Module at STC

\begin{tabular}{|c|c|}
\hline Parameter & Solar cell \\
\hline Voltage at maximum power & $35.4 \mathrm{~V}$ \\
\hline Current at maximum power & $4.9 \mathrm{~A}$ \\
\hline Open circuit voltage & $44.5 \mathrm{~V}$ \\
\hline Short circuit current & $5.5 \mathrm{~A}$ \\
\hline Number of cells for module & 72 \\
\hline Temp. coeff. at open circuit voltage & $-(160 \pm 20) \mathrm{mV} /{ }^{\circ} \mathrm{C}$ \\
\hline Temp. coeff. at short circuit current & $(0.065 \pm 0.015) \% /{ }^{\circ} \mathrm{C}$ \\
\hline NOCT & $47^{\circ} \mathrm{C}$ \\
\hline
\end{tabular}

The I-V characteristics for various conditions of solar irradiation and cell temperature of $25^{\circ} \mathrm{C}$ are shown in Figure 3.

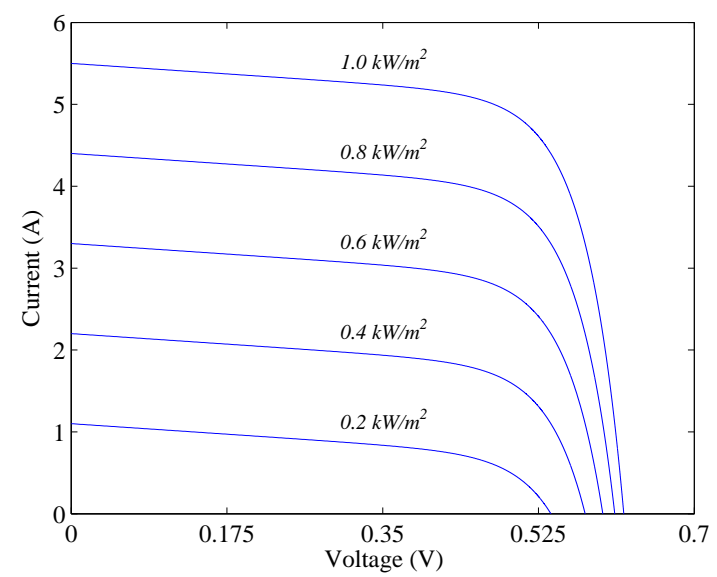

Fig. 3. I-V characteristics for various conditions of solar radiation and cell temperature of $25^{\circ} \mathrm{C}$.

The P-V characteristics for various conditions of temperature and $1000 \mathrm{~W} / \mathrm{m}^{2}$ of solar irradiation are shown in Figure 4.

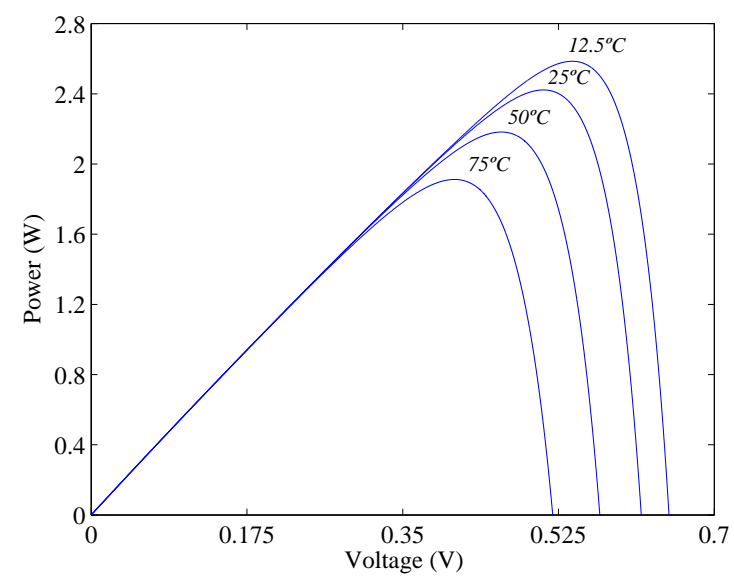

Fig. 4. P-V characteristics for various conditions of temperature and $1000 \mathrm{~W} / \mathrm{m}^{2}$ of solar irradiation.
As shown in Figure 4, an increase of cell temperature causes a decrease in the output power of solar cell.

The variation of the diode saturation current with cell temperature is shown in Figure 5.

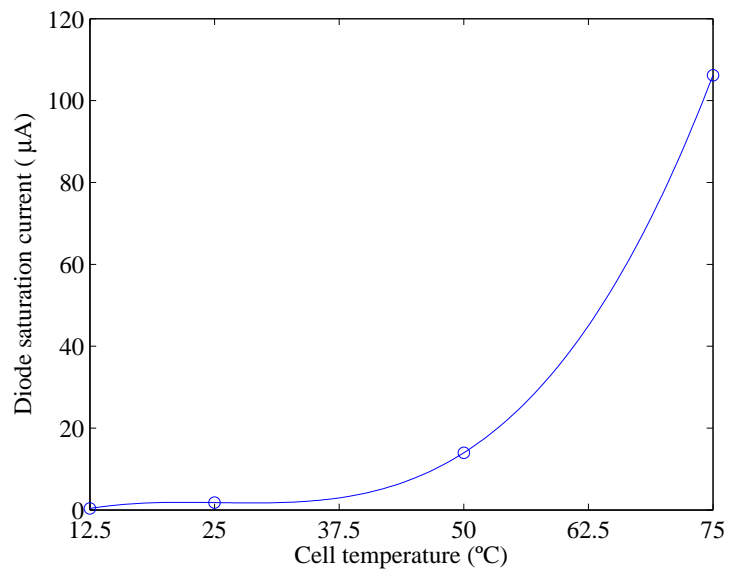

Fig. 5. Variation of the diode saturation current with cell temperature.

The output power variation for various conditions of temperature and $1000 \mathrm{~W} / \mathrm{m}^{2}$ of solar irradiation are shown in Figure 6.

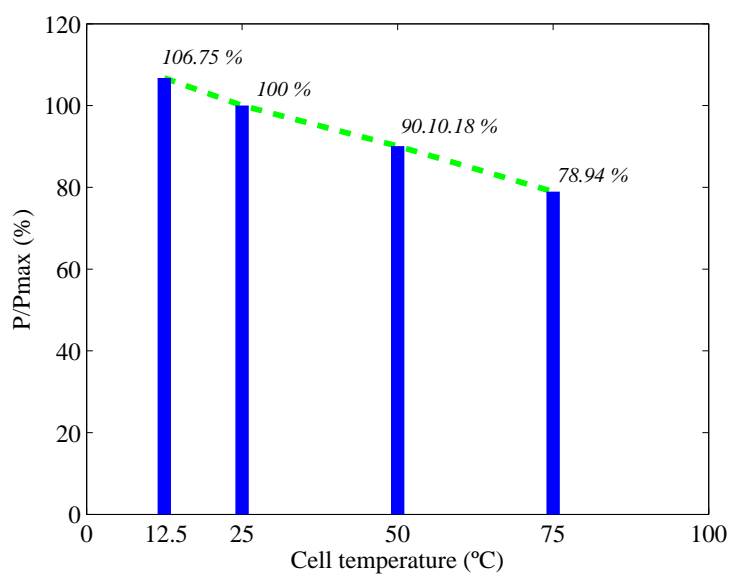

Fig. 6. Output power variation for various conditions of temperature and $1000 \mathrm{~W} / \mathrm{m}^{2}$ of solar irradiation.

As shown in Figure 6, an increase of cell temperature causes a less pronounced decrease in the output power of solar cell.

\section{Conclusion}

The behaviour of a solar cell model, considering a solar cell with single-diode, series and shunt resistances, is studied in this paper. The computational simulations consider temperature dependence and solar radiation change. Meaningless negative series resistance is avoided with the novel iterative procedure.

\section{References}

[1] H.-L. Tsai, "Insolation-oriented model of photovoltaic module using Matlab/Simulink", Solar Energy, Vol. 84, pp. 1318-1326, 2010. 
[2] F. Spertino and J. S. Akilimali, "Are manufacturing I-V mismatch and reverse currents key factors in large photovoltaic arrays?", IEEE Transactions on Industrial Electronics, Vol. 56, No. 11, pp. 4520-4531, Nov. 2009.

[3] G. Spagnuolo, G. Petrone, S.V. Araújo, C. Cecati, E. F.Madsenl, E. Gubía, D. Hissel, M. Jasinski, W. Knapp, M. Liserre, P. Rodriguez, R. Teodorescu, P. Zacharias, "Renewable energy operation and conversion schemes", IEEE Industrial Electronics Magazine, Vol. 4, No. 1, pp. 38-51, 2010.

[4] M. Laranja, "Portuguese National Strategy ENE 2020". Available: http://www.ccr-norte.pt/norte2020/laranja.pdf.
[5] M. G. Villalva, J. R. Gazoli, and E. R. Filho, "Comprehensive approach to modeling and simulation of photovoltaic arrays", IEEE Transactions on Power Electronics, Vol. 24, No. 5, pp. 1198-1208, May 2009.

[6] K. Ishaque, Z. Salam, H. Taheri, "Simple, fast and accurate two-diode model for photovoltaic modules", Solar Energy Materials and Solar Cells, Vol. 95, No. 2, pp. 586-594, 2011.

[7] BP Solar Products Information [On line], Available: http://www.bp.com. 